\title{
Study of Annealing Effect on Characteristics of Nickel Boron Alloy Thin Films
}

\author{
Baskar T ${ }^{1,1}$, A.Shaji George ${ }^{2}$ \\ ${ }^{1}$ Post-Doctoral Researcher, Department of Physics, Crown University, Int'1. Chartered Inc. (CUICI) Argentina \\ Campus, South America. \\ ${ }^{1}$ Professor, Department of Physics, Shree Sathyam College of Engineering and Technology, Sankari Taluk, Salem \\ District, Tamil Nadu ,India. \\ ${ }^{3}$ Professor, Department of Information and Communication Technology, Crown University, Int'l. Chartered Inc.
}

(CUICI) Argentina Campus, South America.

\begin{abstract}
Alloy thin films of $\mathrm{NiB}$ were prepared using electroplating at room temperature. Then electroplated $\mathrm{NiB}$ thin films was annealed at $200 \mathrm{o} \mathrm{C}$. NiB deposited films are textured with FCC phase preferred orientation. They were subjected to morphological, structural, and mechanical characterization analysis. NiB films were bright and uniformly coated on the surface. Also, the deposits of $\mathrm{NiB}$ films were in nano scale and the average crystalline size was around 61 $\mathrm{nm}$. The micro hardness of $\mathrm{NiB}$ was $112 \mathrm{VHN}$ after annealing .
\end{abstract}

Keywords: Electroplating, electrolytic bath, crystalline size, VSM, Ni-B, X-ray diffraction, VHN, SEM.

\section{INTRODUCTION}

Several physical and chemical processes, such as thermal decomposition method, co-precipitation, spray pyrolysis, and electro deposition, can be used to make NiB alloy thin films [1-3]. Electro deposition is a surface structure modification technology that uses an electrochemical process. Electro deposition, when compared to other deposition processes, is one of the most promising due to its precise control, low cost, simple setup, and potential compatibility [4-7]. The use of nickel boron alloy sheets in MEMS would allow for more efficient sensing, storage, and transduction capabilities, as well as increased adaptability and performance of present MEMS [8-10]. Nickel is a well-known soft magnetic substance that contains boron [11-13]. Transformers, inductors, magnetic amplifiers, magnetic shields, and memory storage devices all use NiB alloy thin films, which offer the best soft magnetic characteristics. The effects of annealing on NiB films were investigated in this work.

\section{EXPERIMENTAL PART}

Electrodeposition of $\mathrm{NiB}$ alloy films were prepared with electrolyte baths consisting Borox (15 g/l), Nickel sulphate (30 $\mathrm{g} / \mathrm{l})$, Ammonium sulphate (40 g/l), Boric acid (10 g/l), and Saccharin (10 g/l) and operating at temperature (30 o C). The deposition process took 15 minutes to complete. Copper and stainless-steel substrates with dimensions of $1.5 \mathrm{~cm} \times 7.5$ $\mathrm{cm}$ were used as cathode and anode in this study [14-16]. By adding ammonia solution, the $\mathrm{pH}$ of the electrolytic solution was set to 6.0, and the electroplating procedure was carried out with a current density of $3 \mathrm{~mA} / \mathrm{cm} 2$. After 15 minutes, the copper or cathode was gently removed from the bath and dried for a few minutes [17]. Then electroplated NiB thin films was annealed at 200 o C. Scanning Electron Microscope was used to describe the surface nature of NiB films. Energy-dispersive X-ray spectroscopy was used to look at the atomic composition of film deposits, and X-ray diffraction was used to look at the crystal structure of the deposits. Vickers Hardness Test was used to determine the micro hardness of the films.

\section{RESULTS AND DISCUSSION}

\section{Elemental Composition of NiB Thin Films}

The elemental composition of NiB films was determined by EDAX analyser. The obtained data by this analyser are shown in Table 1. From result, after annealing, boron increased, and nickel decreased . 
International Advanced Research Journal in Science, Engineering and Technology

Vol. 8, Issue 9, September 2021

DOI: 10.17148/IARJSET.2021.8939

Table.1: EDAX analysis of thin films

\begin{tabular}{|l|l|l|l|}
\hline S. No & Condition & Ni Wt\% Wt\% & B Wt \% \\
\hline 1 & NiB $\left(30^{\circ} \mathrm{C}\right)$ & 73.23 & 26.77 \\
\hline 2 & $\begin{array}{l}\text { NiB (Annealed } \\
\left.200^{\circ} \mathrm{C}\right)\end{array}$ & 69.81 & 30.19 \\
\hline
\end{tabular}

\section{Morphological Observation}

Surface appearance of $\mathrm{NiB}$ thin films at $30^{\circ} \mathrm{C}$ and annealed thin film were analysed by Scanning Electron Microscope (SEM) images and they are shown in Fig 1. The thin films are bright and uniformly coated on the surface. They are crack free by appearance.

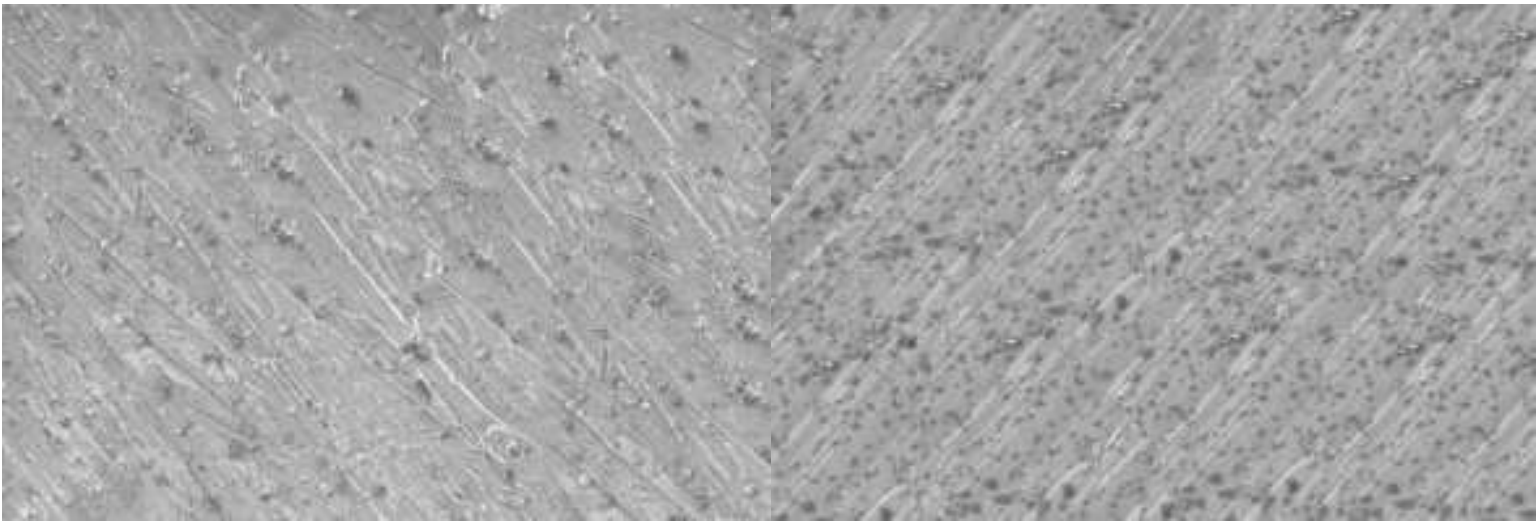

(a)

(b)

Fig 1. SEM Images of thin films (a) $\mathrm{NiB}\left(30^{\circ} \mathrm{C}\right)(\mathrm{b}) \mathrm{NiB}\left(\right.$ Annealed $200^{\circ} \mathrm{C}$ )

\subsection{Structural Characters}

Structural characteristic (from XRD Data) results of deposited materials prepared with temperature $30^{\circ} \mathrm{C}$ and annealed thin film are shown in figure 2. From XRD pattern of NiB, crystal formation of deposits can be concluded. The size of crystals of can be determined by formula

$$
\text { Crystal Size }(D)=(0.955 \lambda) / \beta \operatorname{Cos} \theta
$$

Where, $\beta$ is FWHM at $2 \theta, \lambda$ is wavelength of incident light. The XRD results of NiB films have shown face centred cubic phase with three diffraction peaks. The nano crystallite deposits was obtained
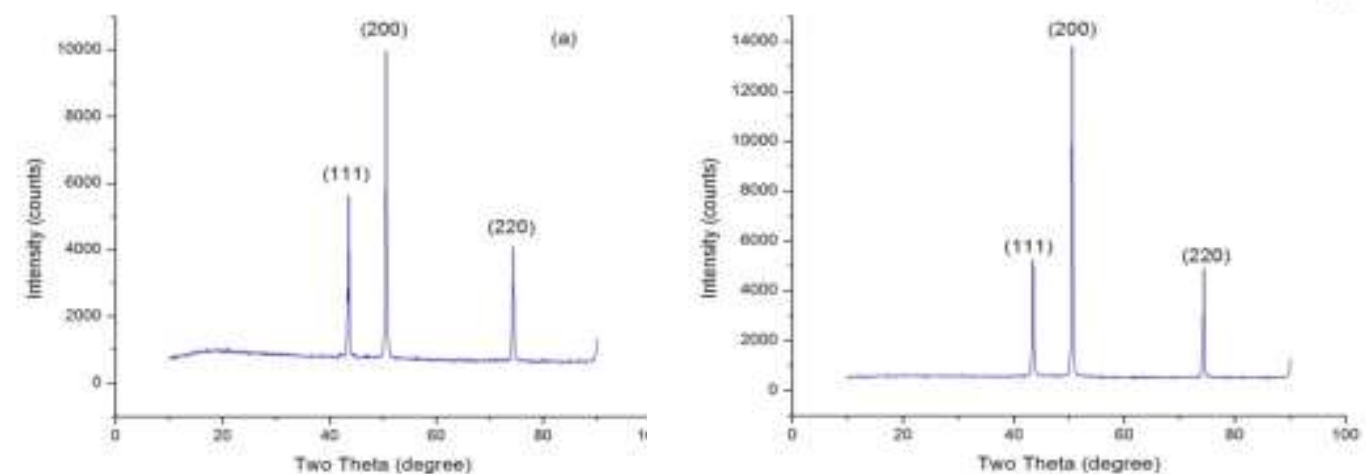

Fig 2. XRD patterns (a) $\mathrm{NiB}\left(30^{\circ} \mathrm{C}\right) \quad$ (b) $\mathrm{NiB}\left(\right.$ Annealed $\left.200^{\circ} \mathrm{C}\right)$ 
International Advanced Research Journal in Science, Engineering and Technology

Vol. 8, Issue 9, September 2021

DOI: $10.17148 /$ IARJSET.2021.8939

The crystallite sizes of $\mathrm{NiB}$ deposits are tabulated in table 2. Annealing process decreases the crystal size.

Table.2: NiB alloy films -Structural properties

\begin{tabular}{|l|l|l|l|l|}
\hline S.No & Condition & $\begin{array}{l}\mathbf{2 \theta} \\
(\mathbf{d e g})\end{array}$ & $\begin{array}{l}\mathbf{d} \\
\left(\mathbf{A}^{\mathbf{0}}\right)\end{array}$ & $\begin{array}{l}\text { Particle Size(D) } \\
(\mathbf{n m})\end{array}$ \\
\hline 1 & $\mathrm{NiB}\left(30^{\circ} \mathrm{C} \&\right.$ without Adenine) & 47.65 & 1.8457 & 65.67 \\
\hline 2 & $\begin{array}{l}\mathrm{NiB} \\
\left(\text { Annealed } 200^{\circ} \mathrm{C}\right)\end{array}$ & 48.03 & 1.8934 & 56.17 \\
\hline
\end{tabular}

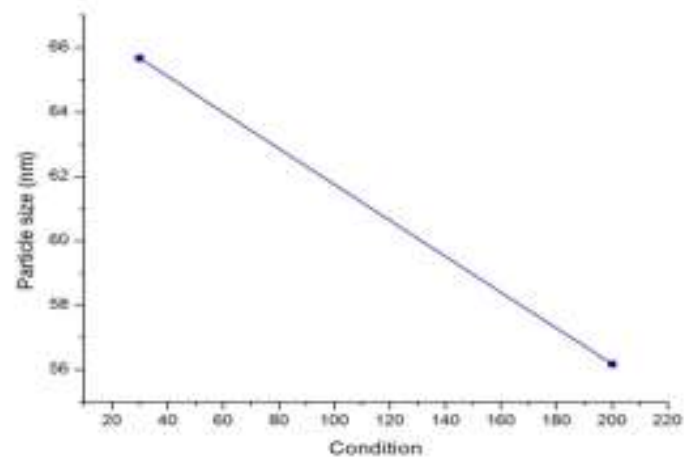

Fig 3. Particle size changes with condition

\subsection{Mechanical Properties}

Micro hardness measurement of deposits was done by Vickers hardness tester. The hardness values of thin films at room temperature $30^{\circ} \mathrm{C}$ and annealed thin film are shown in table 3 . Annealing process increases the hardness, because of onset formation of crystal deposits during electro deposition process.

Table.3: NiB alloy films -Hardness

\begin{tabular}{|l|l|l|}
\hline S.No & Condition & Hardness VHN) \\
\hline 1 & $\mathrm{NiB}\left(30^{\circ} \mathrm{C}\right)$ & 93 \\
\hline 2 & $\mathrm{NiB}\left(\right.$ Annealed $\left.200^{\circ} \mathrm{C}\right)$ & 112 \\
\hline
\end{tabular}

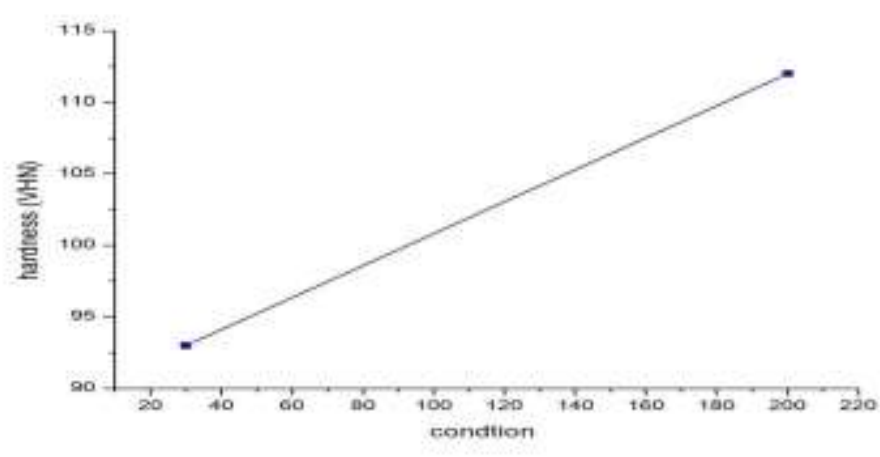

Fig 4. Hardness changes with condition 


\section{International Advanced Research Journal in Science, Engineering and Technology}

Vol. 8, Issue 9, September 2021

DOI: $10.17148 /$ IARJSET.2021.8939

CONCLUSION

An alloy thin films NiB has been prepared by electro deposition method. The characteristics of NiB films were observed. From EDAX result, boron increased, and nickel decreased after annealing. The XRD results of NiB films have shown face centered cubic phase with three diffraction peaks. The thin films prepared with annealing process are bright and uniformly coated on the surface. They are crack free by appearance. The hardness values of thin films after annealing process increases.

\section{REFERENCES}

1. E. Jartych, M. Jalochowski, M. Budzynski, Influence of the electrodeposition parameters on surface morphology and local magnetic properties of thin iron layers, Appl. Surf. Sci. 193 (2002) 210-216.

2. Y. Motomura, T. Tatsumi, H. Urai, M. Aoyama, Soft magnetic properties and heat stability for Fe/NiFe super lattices, IEEE Transactions on Magnetics 26 (1990) 2327-2331.

3. N. Gupta, A. Verma, S.C. Kashyap, Dielectric behavior of spin-deposited nano crystalline nickel-zinc ferrite thin films processed by citrateroute, Solid State Commun. 10 (2005) 689-694.

4. K. Sridharan, K. Sheppard, Electrochemical characterization of Fe-Ni-P alloy electrodeposition, J. Appl. Electrochem. 27 (1997) 11981206.

5. N. Gupta, A. Verma, S.C. Kashyap, Dielectric behavior of spin-deposited nanocrystalline nickel-zinc ferrite thin films processed by citrateroute, Solid State Commun. 10 (2005) 689-694.

6. Y. Chen, Q.P. Wang, C. Cai, Y.N. Yuan, F.H. Cao, Z. Zhang, J.Q. Zhang, Electrodeposition and characterization of nanocrystalline CoNiFe films, Thin Solid Films, 520 (2012) 3553-3557.

7. L. Chih-Huang, H. Matsuyama, R.L. White, T.C. Anthony, Anisotropic exchange for NiFe films grown on epitaxial NiO, IEEE Transactions on Magnetics 31(6) (1995) 2609-2611.

8. Sulztanu, N.; Fbrinza, J.; Electrodeposited Ni-Fe-S films with high resistivity for Magnetic recording devices, J. Optoelectron Adv Mat., 2004, 6, 641- 645 .

9. Esther, P.; Joseph Kennady,C.; Effect of sodium tungstate on the properties of Electrode posited nanocrystalline NiFeCr films, Journal of Non Oxide Glasses., 2010, 1, 35-44.

10. Sulztanu, N.; Fbrinza, J.; Electrodeposited Ni-Fe-S films with high resistivity for Magnetic recording devices, J. Optoelectron Adv Mat., 2004, 6, 641- 645 .

11. Hamid, Z.A.; Electrodeposition of Cobalt- Tungsten Alloys from Acidic Bath Containing Cationic Surfactants, Materials Letters,2003, 57, 2558 .

12. Y. Motomura, T. Tatsumi, H. Urai, M. Aoyama, Soft magnetic properties and heat stability for Fe/ NiFe super lattices, IEEE Transactions on Magnetics 26 (1990) 2327-2331.

13. Kannan, R.; Ganesan, S.; Selvakumari ,T.M.; Synthesis and characterization of nano crystalline NiFeWS thin films in diammonium citrate bath, Digest journal of nanomaterials and biostructures, 2012,7, 1039-1050.

14. C.Z. Yao, P. Zhang, M. Liu, G.R. Li, J.Q. Ye, P. Liu, Y.X. Tong, Electrochemical preparation and magnetic study of Bi-Fe-Co-Ni-Mn high entropy alloy, Electrochim. Acta. 53 (2008) 8359-8365

15. M. Bedir, O.F. Bakkaloglu, I.H. Karahan, M. Oztas, A study on electrodepisted NixFe1-x alloy films,Pramana. 66(6) (2006) 1093-1104.

16. Myung, N.; A Study on the Electrodeposition of NiFe Alloy Thin Films Using Chronocoulometry and Electrochemical Quartz Crystal Microgravimetry, Bull. Korean Chem. Soc., 2001, 22, 994-998

17. Emerson, R.N.; Kennady, C.J.;.Ganesan, S.; Effect of Organic additives on the Magnetic properties of Electrodeposition of CoNiP Hard Magnetic Films, Thin solid films, 2007,515, 3391-3396.

18. Durairaj P.; Venkateswari P.; Sruthipriya D; Mr. Manjunathan; Maruthavanan T.. "Synthesis and Biological Screening of Some New Schiff Base Nickel (II) Complexes". International Research Journal on Advanced Science Hub, 2, Special Issue ICAMET 10S, 2020, 62-70. doi: 10.47392/irjash.2020.200 